\title{
MEDIASI DAN PENGARUH SWITCHING COST TERHADAP LOYALITAS PELANGGAN GSM
}

\author{
Rina Astini \\ Jurusan Manajemen, Fakultas Ekonomi, Universitas Mercu Buana, \\ Kampus Menteng, Jln. Menteng Raya No.29, Jakarta Pusat
}

\begin{abstract}
Article presents a measurement of the effects of satisfaction and trust in connection with customer loyalty, and a direct and indirect effects of switching cost on customer loyalty. Data were collected from 42 respondents coming from GSM customers. Data was analyzed by using path analysis methods. The study found that satisfaction did not necessarily affect customers' loyalty. Relationship of customer satisfaction and trust was greatly influenced by perception of customers towards the cost of switching. Level of satisfaction and respondent loyalty average was $69.7 \%$ and the average value of customer loyalty was $78.73 \%$. The research result indicates that trust and switching cost jointly influence customer loyalty. Trust is more important than customer satisfaction in influencing customer loyalty, where the trust contains belief towards a brand, which will produce a positive outcome both in the present and in the future. Customer satisfaction does not contain this dimension. It is concluded that GSM operators shall have to focus on trust rather than satisfaction.
\end{abstract}

Keywords: switching costs, customer loyalty, GSM

\begin{abstract}
ABSTRAK
Artikel bertujuan mengukur efek kepuasan dan kepercayaanyang terkait dengan loyalitas pelanggan, serta efek langsung dan tidak langsung dari biaya beralih terhadap loyalitas pelanggan. Data dikumpulkan dari 42 responden pelanggan GSM. Data dianalisis dengan metode analisis jalur. Dari hasil studi ditemukan bahwa kepuasan tidak serta merta mempengaruhi loyalitas pelanggan. Hubungan kepuasan pelanggan dan kepercayaan sangat dipengaruhi oleh seberapa besar persepsi pelanggan terhadap biaya beralih. Tingkat kepuasan dan loyalitas responden secara rata-rata kepuasan 69,7\% dan nilai rata-rata loyalitas pelanggan 78,73\%. Hasil penelitian menunjukkan bahwa kepuasan, kepercayaan, dan biaya beralih secara bersama-sama mempengaruhi loyalitas pelanggan; kepercayaan lebih penting daripada kepuasan pelanggan dalam mempengaruhi loyalitas pelanggan, yaitu kepercayaan berisi belief terhadap suatu merek yang akan menghasilkan outcome positif baik saat ini maupun yang akan datang. Sedangkan kepuasan pelanggan tidak berisi dimensi ini. Disimpulkan, operator GSM harus menitikberatkan pada kepercayaan daripada kepuasan.
\end{abstract}

Keywords: switching cost, loyalitas pelanggan, GSM 


\section{PENDAHULUAN}

Globalisasi yang didorong oleh kemajuan pesat di bidang teknologi, terutama teknologi telekomunikasi menyebabkan semakin derasnya arus informasi dengan segala dampaknya, baik positif maupun negatif. Menurut International Telecommunications Union (ITU), setiap peningkatan 1\% telekomunikasi suatu negara akan memberi kontribusi kepada peningkatan pertumbuhan ekonomi nasional sebesar 3\%. Hal ini bisa dilihat dari negara-negara yang baru tumbuh seperti Korea Selatan, China, dan Malaysia (Driyo dalam Economic Review 2006).

Berdasarkan Asosiasi Telepon Seluler Indonesia (ATSI), terdapat 11 perusahaan yang mendapatkan izin sebagai operator telepon seluler di Indonesia, tetapi yang beroperasi sebanyak 9 perusahaan. Dari jumlah tersebut, 6 di antaranya adalah pemain lama dan 3 perusahaan lainnya adalah pemain baru. Namun, dari jumlah tersebut, yang menggunakan sistem digital GSM dan teknologi CDMA masing-masing 4 perusahaan, yang menggunakan sistem AMPS/NMT ada 2 perusahaan, dan 1 perusahaan menggunakan teknologi NMT 450 (Tabel 1).

"GSM" kepanjangan dari Global System for Mobile Communication, yang merupakan standar komunikasi seluler yang berbasis komunikasi digital. Teknologi GSM hingga kini masih tetap diadopsi oleh 4 perusahaan operator seluler seperti PT Telkomsel (Simpati), PT Excelcomindo (Pro XL), PT Natrindo Telepon Seluler/Lippo Telecom (Cermat), dan PT Indosat Tbk (Mentari, IM3, Matrik). Namun, saat ini muncul operator baru dengan bendera three (3) yang dimiliki oleh PT Cyber Access Communication, yang mengusung teknologi GSM 1800 dan WCDMA (Data ATSI:2004).

Gerpott et al. (2001: 249) menggarisbawahi "dalam jasa telekomunikasi, seringkali terlihat bahwa sekali pelanggan telah menggunakan jasa dan terhubung ke jaringan operator tertentu, hubungan jangka panjang yang terjalin di antara mereka akan menentukan sukes tidaknya suatu perusahaan bersaing, dibandingkan mereka yang di industri di luar jasa telekomunikasi."

Dalam kondisi seperti itu, melindungi existing customer base dan mempertahankan loyalitas pelanggan merupakan keunggulan kompetitif yang sangat krusial. Loyalitas pelanggan adalah komponen kunci kelangsungan hidup suatu merek (Krishnamurti dan Raj, 2001). Oliver (1997: 392) mendefinisikan loyalitas pelanggan sebagai "sebuah komitmen yang kuat untuk membeli kembali atau berlangganan kembali sebuah produk/jasa secara konsisten di masa yang akan datang. Dengan demikian, mengakibatkan pembelian secara berulang merek yang sama atau brand-set yang sama, meskipun pengaruh situasional dan kekuatan marketing bisa menyebabkan perilaku beralih (switching behaviour). Walaupun masih banyak definisi dari loyalitas pelanggan, kelihatannya jelas bahwa ada 2 macam loyalitas pelanggan, yaitu stokastik dan deterministik.

Apapun definisi dari loyalitas pelanggan, dalam rangka untuk meningkatkan loyalitas pelanggan, maka operator telekomunikasi membutuhkan (1) menaikkan tingkat kepuasan pelanggan, dengan cara menaikkan kualitas jasa yang diberikan (Andersen dan Sullivan, 1993); (2) memastikan bahwa pelanggan percaya (trust) dengan perusahaan (Fournier, 1998; Gunlach et al., 1995); (3) memberikan biaya penalti jika berpindah ke operator lain, walaupun merupakan pilihan yang tidak menarik (Fornell, 1992).

Dalam penelitian ini, biaya penalti yang dibayar ketika meninggalkan satu operator ke operator yang lain dikategorikan sebagai biaya beralih ke pelanggan (Switching Cost) (Porter, 1998). Switching Cost merupakan faktor yang sangat penting karena bisa membantu perkembangan loyalitas pelanggan dan menjadikan perusahaan sedikit terpengaruh oleh fluktuasi dalam tingkat kualitas jasa, dalam jangka pendek. Faktanya, baik teori dan studi empiris menunjukkan bahwa Switching Cost memainkan peranan yang sangat penting dalam menjaga pelanggan suatu perusahaan dan 
meningkatkan competitive advantage (Farrel dan Shapiro, 1998; Klemper, 1987a, 1995). Oleh karena itu, saat ini perusahaan berkonsentrasi dalam kegiatan marketing secara langsung menggunakan penalti ini (Burnhamm et al., 2003).

Ketika harga naik, pelanggan menjadi kurang sensitif terhadap tingkat kepuasan (Hauser et al., 1994). Bagaimanapun, struktur pasar mempengaruhi efek dari Switching Cost terhadap hubungan kepuasan pelanggan dan loyalitas pelanggan. Jika pasar dari operator begitu besar, maka efek dari Switching Cost terhadap loyalitas pelanggan dan kepuasan pelanggan akan rendah,.maka pelanggan yang tidak puas akan terus menggunakan satu saja merek, walaupun penaltinya tinggi dan mereka tidak punya pilihan lain untuk pindah (Feick et al., 2001). Ketika alternatif ada dan Switching Cost rendah, pelanggan yang tidak puas dapat dengan mudah pindah ke kompetitor.

Dalam banyak kasus yang telah diteliti, hubungan antara loyalitas pelanggan dan kepuasan pelanggan sangat kuat untuk segmen pelanggan yang memiliki Switching Cost yang tinggi (Bloemer et al., 1998; Jones et al., 2000). Bagaimanapun, Patterson dan Sharma (2000) menjelaskan bahwa jika Switching Cost naik, maka kekuatan hubungan antara kepercayaan dan komitmen juga ikut naik. Semua penelitian mengatakan bahwa Switching Cost memiliki efek moderasi dalam anteseden loyalitas pelanggan seperti kepuasan pelanggan dan trust.

Umumnya, walaupun biaya penalti yang diberlakukan berperan secara potensial dalam loyalitas pelanggan, topik ini menarik untuk dikaji karena terbatasnya penelitian, di mana riset saat ini terhadap loyalitas pelanggan hanya menitikberatkan pada kepuasan pelanggan, kualitas jasa, dan trust. Oleh karena itu, tulisan ini akan meneliti kekurangan dari penelitian yang ada dengan menguji efek langsung dan tidak langsung dari trust dan kepuasan pelanggan dalam loyaltias pelanggan, dan efek mediasi dari Perceived Switching Cost terhadap loyalitas pelanggan.

Dari uraian di atas, masalah kepuasan pelanggan, Perceived Switching Cost dan trust menjadi menarik untuk dibahas, untuk melihat sejauh mana loyalitas pelanggan telepon seluler GSM dalam mengggunakan jasa layanan telepon. Oleh karena itu, penulis akan menentukan identifikasi masalah sebagai berikut: (1) Bagaimana loyalitas pelanggan GSM di indonesia sampai saat ini?; (2) Sejauh mana pengaruh kepuasan pelanggan dan Trust dalam jasa telepon seluler GSM terhadap loyalitas pelanggan?; (3) Sejauh mana pengaruh langsung dan tidak langsung dari Perceived Switching Cost terhadap loyalitas pelanggan?; dan (4) Apa saja yang harus dilakukan operator layanan seluler GSM dalam mengelola pelanggannya sehingga loyalitas pelanggan tetap terjaga?.

Secara garis besar, konsep Service mengacu pada 3 lingkup definisi utama, yaitu industri, output atau penawaran, dan proses (Jhons, 1999). Dalam konteks industri, istilah jasa digunakan untuk menggambarkan berbagai sub-sektor dalam kategorisasi aktifitas ekonomi seperti transportasi, finansial, perdagangan ritel, personal services, kesehatan, pendidikan, dan layanan publik. Dalam lingkup penawaran, jasa dipandang sebagai produk intangible yang output-nya lebih berupa aktifitas ketimbang objek fisik, meskipun dalam kenyataannya, banyak pula jasa yang melibatkan produk fisik (contohnya adalah makanan di restoran dan pesawat di jasa penerbangan). Sebagai proses jasa mencerminkan penyampaian jasa inti, interaksi personal, kinerja (performances) dalam arti luas (termasuk di dalamnya darama dan keterampilan) serta pengalaman layanan.

Menurut Kotler (2003); Kotler et al. (2004); Solomon dan Stuart (2003); Fisk, Grove dan Jhon (2004) serta Zeithaml dan Bitner (2003), terdapat 4 karakteristik sebagai berikut. Pertama, Intangibility. Jasa bersifat intangible, artinya adalah jasa tidak dapat dilihat, dirasa, dicium, didengar, atau diraba sebelum dikonsumsi atau dibeli. Konsep intangible memiliki 2 pengertian (Berry, 1980), yaitu (1) sesuatu yang tidak dapat disentuh dan tidak dapat dirasakan; dan (2) sesuatu yang tidak mudah didefinisikan, dirumuskan atau dipahami secara rohaniah. Kedua, Heterogeneity/ Variability/ Inconsistency. Jasa bersifat sangat variabel karena merupakan non-standadized output, artinya terdapat banyak variasi bentuk, kualitas, dan jenis, tergantung pada siapa, kapan dan di mana jasa tersebut 
diproduksi. Menurut Boove, Houston dan Thill (1995), dalam Tjiptono terdapat 3 faktor yang menyebabkan variabilitas kualitas jasa, yaitu kerjasama atau partisipasi pelanggan selama penyampaian jasa, moral/motivasi karyawan dalam melayani pelanggan, dan beban kerja perusahaan. Ketiga, Inseparability. Jasa umumnya dijual terlebih dahulu, baru kemudian diproduksi dan dikonsumsi pada waktu dan tempat yang sama. Interaksi antara penyedia jasa dan pelanggan merupakan ciri khusus dalam pemasaran jasa. Keduanya mempengaruhi hasil (outcome) dari jasa bersangkutan. Dalam hubungan antara penyedia jasa dan pelanggan ini, efektifitas individu yang menyampaikan jasa (contact-personnel) merupakan unsur kritis. Implikasinya, kunci keberhasilan bisnis jasa terdapat pada proses rekrutmen dan seleksi, penilaian kinerja, sistem imbalan, pelatihan, dan pengembangan karyawannya. Keempat, Perishability. Perishability berarti jasa merupakan komoditas yang tidak tahan lama, tidak dapat disimpan untuk pemakaian ulang di waktu mendatang, dijual kembali atau dikembalikan (Zeithalm dan Bitner, 2003).

Pelanggan tidak semata-mata membeli barang atau jasa, melainkan mereka membeli manfaat yang diberikan oleh barang atau jasa bersangkutan (Levitt, 1980). Gronroos (2000) menegaskan bahwa setiap perusahaan (pemanufaktur maupun organisasi jasa, beroperasi dalam pasar konsumen maupun pasar industrial), perlu mempertimbangkan perspektif jasa (servis perspektif) dalam strategi bersaingnya. Gronroos (2000) mengidentifikasikan 4 perspektif strategik utama, yaitu perspektif produk inti (Core Product Perspective), perspektif harga (Price Perspective), perspektif citra (Image Perspective), dan perspektif jasa.

Pertama, perspektif produk inti (Core Product Perspective). Perspektif ini berkonsentrasi pada pengembangan solusi inti, baik berupa produk fisik maupun jasa, sebagai penyedia nilai utama bagi proses penciptaan nilai pelanggan. Layanan/Jasa tambahan bisa dipandang penting, namun tidak strategik sehingga cenderung hanya mendapatkan prioritas rendah. Hidden service terutama yang nonbillable tidak dipandang sebagai value enhanching services.

Kedua, perspektif harga (Price Perspective). Perspektif ini menganggap bahwa harga merupakan kriteria pembelian terpenting di antara para pelanggannya sehingga kemampuan menawarkan harga murah merupakan faktor krusial dalam rangka mempertahankan survivabilitas di pasar. Harga dipandang sebagai kontributor utama bagi proses penciptaan nilai pelanggan. Penyediaan jasa/layanan tambahan tidak dianggap sebagai proses penambahan nilai sehingga prioritasnya lebih rendah dibandingkan kapabilitas menawarkan solusi berharga murah.

Ketiga, perspektif citra (Image Perspective). Perspektif ini menekankan pentingnya diferensiasi berdasarkan citra merek atas produk inti yang ditawarkan perusahaan. Citra semacam ini terbentuk dalam benak konsumen melalui periklanan dan komunikasi pemasaran lainnya. Solusi inti dipandang sebagai titik awal bagi pengembangan nilai pelanggan. Namun, citra merek yang dihasilkan dari aktifitas pemasaran diyakini sebagai kontributor utama bagi proses penciptaan nilai pelanggan.

Keempat, perspektif jasa. Perspektif ini berkeyakinan bahwa solusi inti (produk fisik, jasa atau kombinasi barang dan jasa) tidak cukup untuk mendiferensiasikan penawaran perusahaan dalam pasar yang sangat kompetitif. Oleh karena itu, Customer's Value generating processes perlu didukung dengan Total Service Offering yang mengintegrasikan komponen produk fisik, jasa/layanan, informasi, perhatian personal, dan elemen-elemen relasi pelanggan lainnya. Hidden service dipandang sebagai komponen penting dalam proses penciptaan nilai pelanggan, sementara harga dipandang kurang penting dibandingkan dengan biaya jangka panjang bagi pelanggan.

Howard dan Sheth (1969) mengungkapkan bahwa kepuasan pelanggan adalah situasi kognitif pembeli berkenaan dengan kesepadanan atau ketidaksepadanan antara hasil yang didapatkan, dibandingkan dengan pengorbanan yang dilakukan. Swan et al. (1980) mendefinisikan kepuasan pelanggan sebagai evaluasi secara sadar atau penilaian kognitif, menyangkut apakah kinerja produk relatif bagus atau jelek atau apakah produk bersangkutan cocok atau tidak cocok dengan 
tujuan/pemakaiannya. Oliver (1981) mengemukakan bahwa kepuasan pelanggan merupakan evaluasi terhadap surprise yang inheren atau melekat pada pemerolehan produk dan atau pengalaman konsumsi. Churchil dan Suprenant (1982) merumuskan kepuasan pelanggan sebagai hasil pembelian dan pemakaian yang didapatkan dari perbandingan antara reward dan biaya pembelian dengan konsekuensi yang diantisipasi sebelumnya.

Kepuasan pelanggan adalah tingkat perasaan seseorang setelah membandingkan kinerja (atau hasil) yang ia rasakan dibandingkan dengan harapannya (Kotler, 2000). Berbagai studi literatur menunjukkan bahwa salah satu definisi yang banyak diacu dalam literatur pemasaran adalah definisi berdasarkan disconfirmation paradigm (Oliver, 1997). Berdasarkan paradigma tersebut, kepuasan pelanggan dirumuskan sebagai evaluasi purna beli, di mana persepsi terhadap kinerja alternatif produk/jasa yang dipilih memenuhi atau melebihi harapan sebelum pembelian. Apabila persepsi terhadap kinerja tidak bisa memenuhi harapan, maka yang terjadi adalah ketidakpuasan. Dengan demikian, ketidakpuasan dinilai sebagai bipolar opposite dari kepuasan (Spreng et al., 1996).

Kepuasan pelanggan berkontribusi pada sejumlah aspek krusial seperti terciptanya loyalitas pelanggan, meningkatnya reputasi perusahaan, berkurangnya elastisitas harga, berkurangnya biaya transaksi masa depan, dan meningkatnya efesiensi dan produktifitas karyawan (Anderson et al., 1994). Di samping itu, kepuasan pelanggan juga dipandang sebagai salah satu indikator terbaik untuk laba masa depan (Fornell, 1992; Kotler, 2000). Fakta bahwa menarik pelanggan baru jauh lebih mahal daripada mempertahankan pelanggan, saat ini menarik perhatian pada kepuasan pelanggan (Fornell dan Wenerfelt, 1987).

Menurut beberapa studi yang telah dilakukan, misalnya (Gronhold et al., 2000); Kristensen et al., 2000); Gerpott et al., 2001; Sharma, 2003; Aydin dan Ozer (2005) memperlihatkan hasil bahwa kepuasan pelanggan secara positif mempengaruhi loyalitas. Meskipun belum ada konsensus mengenai cara mengukur kepuasan pelanggan, sejumlah studi menunjukkan bahwa ada 3 aspek penting yang perlu ditelaah dalam kerangka pengukuran kepuasan pelanggan (Fornell, 1992; Fornell et al., 1996), yaitu (1) kepuasan general atau keseluruhan (overall satisfaction); (2) konfirmasi harapan (confirmation of expectations), yakni tingkat kesesuaian antara kinerja dengan ekspektasi; dan (3) perbandingan dengan situasi ideal (comparison to ideal), yaitu kinerja produk dibandingkan dengan produk ideal menurut persepsi konsumen. Pengukuran Overall Customer Satisfaction (kepuasan pelanggan keseluruhan) dalam studi ini dilakukan dengan cara (1) mengukur tingkat kepuasan pelanggan terhadap produk atau jasa perusahaan bersangkutan; (2) menilai dan membandingkannya dengan tingkat kepuasan pelanggan keseluruhan terhadap produk atau jasa pesaing (Tjiptono, 2004).

Biaya beralih (Switching Cost) lebih merupakan one-time cost dan bukan ongoing cost (Porter, 1980). Berdasarkan perspektif ini, Burnham et al., (2003) mendefinisikan biaya beralih sebagai one-time cost, yang dipersepsikan atau diasosiasikan pelanggan dengan proses beralih dari penyedia jasa/produk yang satu ke penyedia jasa/produk yang lain. Biaya-biaya semacam itu tidak terbatas pada biaya ekonomis, namun bisa meliputi berbagai macam biaya seperti biaya pencarian, biaya transaksi, biaya belajar, diskon pelanggan loyal, kebiasaan pelanggan (Consumer Habit), biaya emosional, usaha kognitif, resiko finansial, resiko sosial, dan resiko psikologis (Fornell, 1992). Biaya beralih juga berkontribusi pada laba yang lebih besar, respon inelastis terhadap harga, hambatan masuk bagi para pendatang baru maupun pesaing lain, dan terciptanya keunggulan strategis yang berkesinambungan (Kerin et al., 1992; Porter, 1980).

Biaya beralih meliputi tiga tipe berikut (Burnham et al., 2003). Pertama, prosedural Switching Cost (Information Switching Costs), yang meliputi biaya resiko ekonomis, biaya evaluasi, set-up costs, dan biaya belajar. Pada prinsipnya, biaya ini menyangkut waktu dan usaha yang dicurahkan. Kedua, Financial Switching Costs (Contractual Switching Costs), terdiri atas benefit lost costs dan monetary loss costs. Secara garis besar, tipe biaya ini menyangkut kehilangan sumber daya yang secara finansial bisa dihitung. Ketiga, Relational Switching Costs, berupa personal relationship loss costs dan brand 
relationship loss costs. Pada prinsipnya, tipe biaya ini berkenaan dengan ketidaknyamanan psikologis atau emosional karena kehilangan identitas dan pemutusan hubungan. Switching Cost memberikan beberapa keuntungan terhadap perusahaan dengan sebuah akibat langsung terhadap level loyalitas pelanggan. Sebagai contoh, Switching Cost akan mengurangi sensitivitas pelanggan terhadap harga dan tingkat kepuasan (Fornell, 1992). Dengan alasan ini, Switching Cost merupakan faktor yang lebih banyak mempengaruhi sensitifitas pelanggan terhadap harga dan juga mempengaruhi loyalitas pelanggan (Eber, 1999; Jones et al., 2002; Bloemer et al., 1998).

Fornell (1992) menjelaskan bahwa hubungan antara kepuasan pelanggan dan loyalitas pelanggan bisa dipengaruhi oleh berbagai macam factor, antara lain tipe industri, biaya beralih (Switching Cost) dan perbedaan tingkat produk dalam katagori produk. Studi empiris dalam beberapa sektor (seperti Jones et al., 2000; Feick et al., 2001) memperlihatkan bahwa akan terjadi hubungan yang lemah antara kepuasan pelanggan dan loyalitas pelanggan dalam segmen pasar dengan pesepsi biaya beralih yang tinggi (High Perceived Switching Cost) dibandingkan dengan dengan segmen pasar dengan biaya beralih yang rendah (Low Perceived Switching Cost). Dengan kata lain, persepsi terhadap biaya beralih (Perceived Switching Cost) bisa menjadi efek yang memoderasi (Moderator Effect) terhadap loyalitas pelanggan.

Di sisi lain, suatu kenaikan dalam persepsi biaya beralih (Perceived Switching Cost) akan mempengaruhi efek langsung kepercayaan terhadap produk/perusahaan (Trust) terhadap loyalitas pelanggan (Sharma, 2003; Patterson dan Sharma, 2000). Dengan kata lain, Perceived Switching Cost sebagai efek yang memoderasi (Moderator Effect) terhadap hubungan antara Trust dan loyalitas pelanggan.

Anderson dan Narus dalam Aydin dan Ozer (2004) menulis bahwa Trust bisa terjadi ketika suatu kelompok percaya bahwa yang dilakukan kelompok lain akan menyebabkan hasil positif bagi mereka. Akibatnya, untuk mempercayai suatu merek, pelanggan harus merasakan kualitas sebagai hal yang positif. Trust telah diakui menjadi hal yang sangat penting dalam mempengaruhi hubungan komitment (Morgan dan Hunt, 1994). Hal ini menunjukkan bahwa jika suatu kelompok percaya terhadap yang lain, akan ikut membangun sikap positif terhadap kelompok tersebut. Faktor Trust terhadap sebuah merek merupakan aspek krusial dalam pembentukan loyalitas merek (Lau dan Lee, 1999). Mereka mendefinisikan Trust terhadap sebuah merek sebagai kesediaan konsumen untuk mempercayai atau mengandalkan merek dalam situasi risiko karena adanya ekspektasi bahwa merek bersangkutan akan memberikan hasil positif. Berdasarkan hasil riset yang mereka lakukan menunjukkan bahwa Trust terhadap merek berkontribusi terhadap minat behavioral loyalitas merek. Trust juga mempengaruhi kredibilitas (Ganesan, 1994) dan kredibilitas mempengaruhi orientasi jangka panjang pelanggan dengan mengurangi persepsi terhadap resiko yang dihubungkan dengan sikap oportunis perusahaan (Erdem et al., 2002; Ganesan, 1994). Secara spesifik, Trust mengurangi ketidakpastian dalam suatu kondisi di mana pelanggan merasa tidak nyaman ketika mereka tahu bahwa mereka dapat menaruh kepercayaan terhadap suatu merek (Chaudhuri dan Holbrook, 2001).

Dalam dekade 2000-an, orientasi perusahaan kelas dunia mengalami pergeseran dari pendekatan konvensional ke arah kontemporer (Bhote, 1996). Pendekatan konvensional menekankan kepuasan pelanggan, reduksi biaya, pangsa pasar, dan riset pasar. Sedangkan pendekatan kontemporer berfokus pada loyalitas pelanggan, retensi pelanggan, zero defection, dan lifelong customers (Tjiptono, 2004). Menurut Schnaars (1998), ada 4 macam kemungkinan hubungan antara kepuasan dan loyalitas pelanggan, yaitu failures, forced loyalty, defectors, dan successes. Oleh karena itu, kepuasan pelanggan harus dibarengi pula dengan loyalitas pelanggan. Pelanggan yang benar-benar loyal, bukan saja sangat potensial menjadi word of mouth advertisers, namun kemungkinan besar juga loyal pada portofolio produk dan jasa perusahaan selama bertahun-tanun (Tjiptono, 2004).

Pengukuran terhadap kepuasan maupun ketidakpuasan pelanggan suatu merek merupakan indikator yang penting dari loyalitas merek. Bila ketidakpuasan pelanggan terhadap suatu merek 
rendah, maka pada umumnya tidak cukup alasan bagi pelanggan untuk beralih mengkonsumsi merek lain, kecuali bila ada faktor-faktor penarik yang sangat kuat. Pelanggan yang puas akan melakukan bisnis lebih banyak dan lebih sering. Mereka juga merekomendasikan perusahaan atau mereka kepada kerabat dan teman-temannya. Menurut Gerson (2001), hubungan antara penjualan, pelayanan, kepuasan, dan profit bersifat langsung. Semakin puas seorang pelanggan, semakin banyak uang yang dibelanjakannya.

Pengukuran terhadap variabeL loyalitas (loyal) ini dilakukan dengan pendekatan sikap dan perilaku. Pengukuran sikap (Attitudinal Measurements) dilakukan terhadap konsistensi pembelian dan pembelian ulang. Seperti yang dikemukakan oleh Morgan dan Hunt (1998); Hennig-Thurau dan Klee (1997); Moorman, Zaltman, dan Deshpande, dalam Seyhmus Baloglu (2002), bahwa konstruk kunci dari relationship marketing adalah hubungan antara kepercayaan dengan komitmen. Komitmen konsumen untuk tetap berhubungan dengan perusahaan karena adanya keyakinan atau kepercayaan kepada perusahaan sehingga akan melakukan pembelian ulang.

Loyalitas terhadap produk/jasa perusahaan (merek) didefenisikan sebagai sikap menyenangi (favorable) terhadap sesuatu merek, yang direpresentasikan dalam pembelian yang konsisten terhadap merek itu sepanjang waktu. Kedua pengukuran tersebut merupakan hasil dari proses psychological or emotional attachment. Di sisi lain, Gale (1997) mengatakan bahwa tingkat loyalitas pelanggan dipengaruhi oleh persepsi konsumen terhadap nilai yang ditawarkan oleh perusahaan. Hasil dari sebuah evaluasi konsumen individual, terhadap suatu produk atau jasa dapat memenuhi harapannya atau mampu memuas-kannya, maka di masa datang akan terjadi pembelian ulang. Menurut Parasuraman et.al. (1998), pelanggan membentuk suatu harapan terhadap nilai dan bertindak serta berdasarkan hal itu. Mereka juga memperhitungkan atau mengevaluasi penawaran mana yang akan memberikan nilai tertinggi. Penawaran yang memenuhi harapan nilai pelanggan mempengaruhi kepuasan dan kemungkinan pelanggan membeli kembali.

Dari teori dan hasil penelitian sebelumnya maka bisa digambarkan kerangka pemikiran atau model dari penelitian seperti Gambar 1.

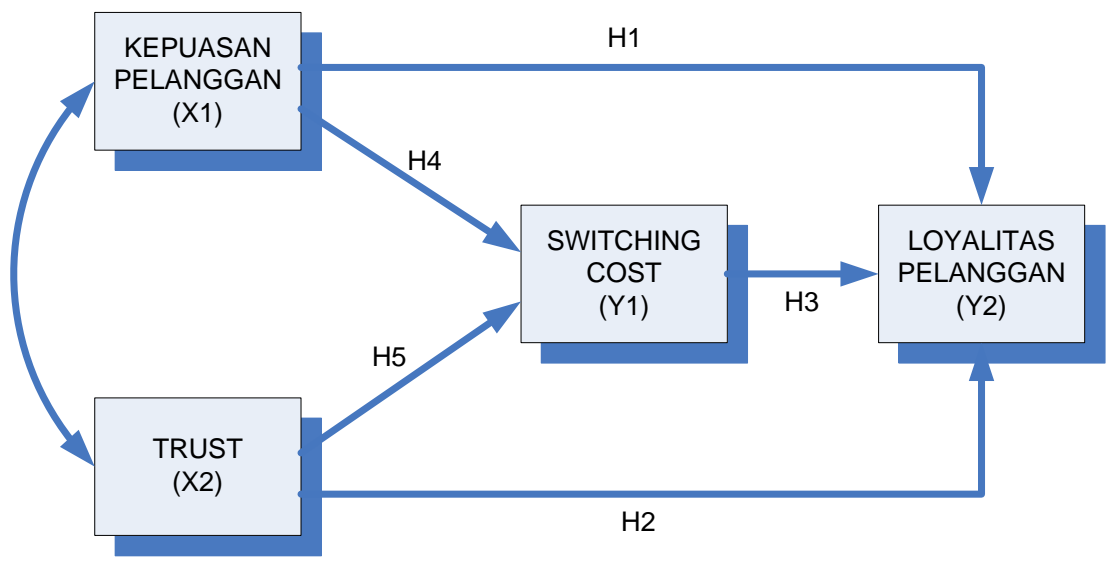

Gambar 1 Kerangka Penelitian/Model Penelitian

Variabel yang akan diukur adalah Trust, Reliability, Ethics, Cumulative Process, Switching Cost, Procedural Switching Cost, Financial Switching Cost, Relational Switching Cost, Customer Loyalty, Repurchase Intention, Resistance to Switching to Competitor, dan Satisfaction. 
Dari kerangka pemikiran di atas, maka dijabarkan hipotesis dari penelitian sebagai berikut:

H1 : Customer Satisfaction memiliki hubungan positif dengan Customer Loyalty.

$\mathrm{H} 2$ : Trust memiliki hubungan positif dengan Customer Loyalty

H3 : Persepsi terhadap Switching Cost berpengaruh positif terhadap loyalitas pelanggan

H4 : Persepsi Switching Cost secara tidak langsung mempengaruhi hubungan antara kepuasan pelanggan dan loyalitas pelanggan.

H5 : Persepsi Switching Cost secara tidak langsung mempengaruhi hubungan antara kepuasan pelanggan dan loyalitas pelanggan.

Penelitian ini menganalisis pengaruh biaya beralih (Switching Cost) terhadap hubungan antara kepuasan pelanggan dan Trust terhadap loyalitas pelanggan. Biaya beralih akan ditempatkan sebagai variabel mediasi yang mempengaruhi loyalitas pelanggan dalam pasar GSM di Indonesia. Penelitian ini akan meneliti hubungan antara masing-masing variabel penelitian dan pengaruhnya satu sama lain. Dalam penelitian ini, yang akan menjadi variabel bebas adalah kepuasan pelanggan dan Trust. Sedangkan yang menjadi variabel mediasi adalah biaya beralih (Switching Cost). Sementara itu, yang akan menjadi variabel tidak bebas adalah loyalitas pelanggan layanan Telekomunikasi seluler berbasis GSM.

Dalam penelitian ini, yang akan dijadikan sebagai responden adalah pelanggan yang menggunakan layanan telepon seluler GSM di Jakarta. Pelanggan seluler yang dimaksud adalah pelanggan seluler GSM yang menggunakan layanan operator GSM, yaitu Telkomsel, Exelcomindo, Indosat, dan HCPT (Three). Teknik pengambilan sampel dilakukan dengan cara probabilty sampling, dengan metode simple random sampling di mana pengambilan sampel dilakukan dengan cara acak tanpa memperhatikan strata yang ada dalam populasi tersebut. Metode ini dilakukan karena populasi pelanggan GSM di Jakarta adalah homogen. Penelitian dilaksanakan selama 2 minggu, yaitu minggu ketiga dan keempat dalam bulan Mei 2007. Waktu tersebut digunakan untuk memperoleh data dan informasi melalui angket yang disebarkan kepada responden.

Metode penelitian yang dilakukan untuk menganalisis "Pengaruh biaya beralih terhadap hubungan antara kepuasan pelanggan dan Trust terhadap loyalitas pelanggan GSM" adalah dengan metode statistik deskriptif. Data statistik yang diolah ada 2, yaitu data kuantitatif dan kualitatif. Dalam penelitian ini, sampel yang akan diambil sebanyak 150 orang di Wilayah Propinsi DKI Jakarta. Sedangkan teknik pengambilan sampel yang digunakan adalah sampel yang dipilih secara acak sederhana (simple random sampling).

Seperti yang terungkap di dalam objek penelitian bahwa pokok masalah yang diteliti adalah bersumber pada 3 hal, yaitu loyalitas pelanggan layanan telepon seluler GSM sebagai variabel tidak bebas kedua (Y2), pengaruh biaya beralih terhadap hubungan tidak langsung antara trust dan kepuasan pelanggan sebagai variabel tidak bebas pertama (Y1), dan sejauhmana Trust dan kepuasan pelanggan dalam mempengaruhi loyalitas pelanggan telepon seluler GSM (X1 dan X2), yang diterangkan pada Gambar 2. Secara rinci, operasionalisasi variabel dalam penelitian ini dapat dikemukakan pada Tabel 1 . 


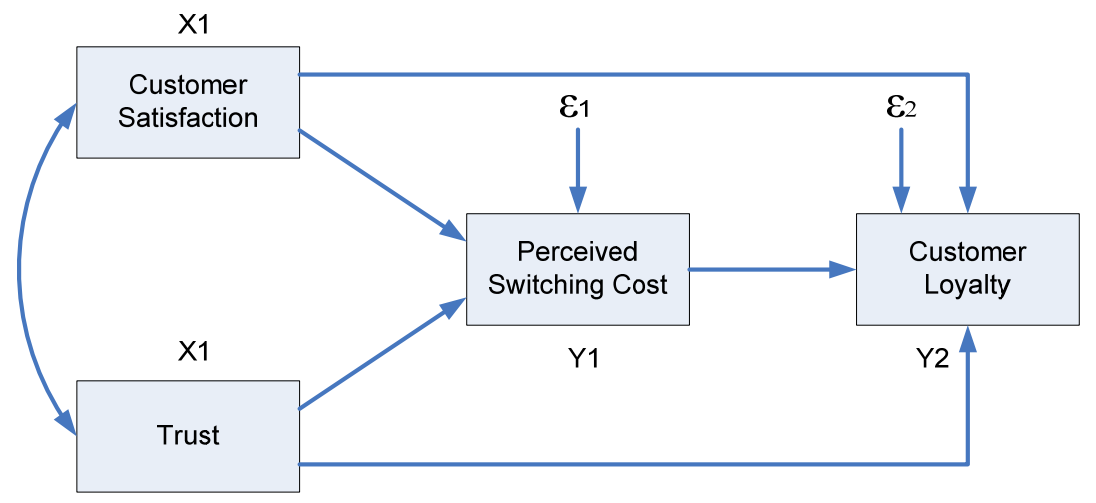

Gambar 2 Operasional Variabel

Tabel 1 Kisi-kisi Instrumen Penelitian

\begin{tabular}{|c|c|c|c|}
\hline Variabel & Konsep Variabel & Indikator & Skala \\
\hline $\begin{array}{l}\text { Loyalitas } \\
\text { pelanggan (Y2) }\end{array}$ & $\begin{array}{l}\text { Kecenderungan seseorang untuk } \\
\text { selalu menunjukkan sikap yang sama } \\
\text { dalam situasi yang sama terhadap } \\
\text { produk yang sebelumnya dibeli. }\end{array}$ & $\begin{array}{l}\text { Kemauan untuk membeli kembali } \\
\text { produk } \\
\text { Resistansi terhadap perpindahan ke } \\
\text { produk kompetitor } \\
\text { Kemauan untuk merekomendasikan } \\
\text { produk ke teman dan kerabatnya }\end{array}$ & Ordinal \\
\hline $\begin{array}{l}\text { Switching Cost } \\
\text { (Biaya Beralih) } \\
\text { (Y1) }\end{array}$ & $\begin{array}{l}\text { One-time cost yang dipersepsikan } \\
\text { atau diasosiasikan pelanggan dengan } \\
\text { proses beralih dari penyedia } \\
\text { jasa/produk yang satu ke penyedia } \\
\text { jasa/produk yang lain. }\end{array}$ & $\begin{array}{l}\text { Perceived monetary costs } \\
\text { Perceived uncertainty costs } \\
\text { Perceived evaluation costs } \\
\text { Perceived learning costs } \\
\text { Perceived set-up costs }\end{array}$ & Ordinal \\
\hline $\begin{array}{l}\text { Trust } \\
\text { (Kepercayaan) } \\
\text { (X2) }\end{array}$ & $\begin{array}{l}\text { Kesediaan konsumen untuk } \\
\text { mempercayai atau mengandalkan } \\
\text { merek dalam situasi risiko karena } \\
\text { adanya ekspektasi bahwa merek } \\
\text { bersangkutan akan memberikan hasil } \\
\text { positif. }\end{array}$ & $\begin{array}{l}\text { Reliability } \\
\text { Ethics } \\
\text { Service Quality } \\
\text { Cumulative Process }\end{array}$ & Ordinal \\
\hline $\begin{array}{l}\text { Kepuasan } \\
\text { Pelanggan (X1) }\end{array}$ & $\begin{array}{l}\text { Situasi kognitif pembeli berkenaan } \\
\text { dengan kesepadanan atau } \\
\text { ketidaksepadanan antara hasil yang } \\
\text { didapatkan dibandingkan dengan } \\
\text { pengorbanan yang dilakukan. }\end{array}$ & $\begin{array}{l}\text { Level of expectation } \\
\text { Level of satisfaction } \\
\text { Level of pre-purchase expectation }\end{array}$ & Ordinal \\
\hline
\end{tabular}

Pengolahan data dimulai dengan mengelompokkan data yang homogeny. Setelah itu, diolah dan dianalisis sehingga data tersebut memiliki makna untuk memberikan pemecahan bagi masalah yang ada dan bermanfaat untuk menguji hipotesis. Tahapan kerja pengolahan data dari kuisioner untuk pengujian hipotesis dapat dikemukakan sebagai berikut (1) Memberi skor pada masing-masing jawaban responden; (2) Memindahkan data dari lembaran kuisioner ke lembar tabulasi; dan (3) Memindahkan data ke lembar kerja kemudian diolah dan dianalisis dengan menggunakan program SPSS 14.

Kuisioner yang diberikan kepada responden dibagi menjadi 2 bagian, yaitu bagian pertama berisi tentang identitas responden, yang meliputi umur, jenis kelamin, pendidikan terakhir, penghasilan per bulan, Operator GSM yang digunakan, dan jenis kartu yang digunakan. Sedangkan bagian kedua 
berisi tentang tanggapan responden mengenai pertanyaan-pertanyaan yang diajukan dalam kuisioner. Jawaban kuisioner yang merupakan data primer digunakan untuk memperoleh nilai-nilai variabel dari kepercayaan, kepuasan, biaya beralih, dan loyalitas pelanggan dengan menggunakan skala likert. Jawaban setiap item instrumen mempunyai tingkatan, dari yang paling positif (diberi skor 7) sampai dengan sangat negatif (diberi skor 1). Penilaian jawaban responden tersebut dapat ditampilkan dalam skala penilaian (Tabel 2).

Tabel 2 Skala Penelitian Jawaban Responden

\begin{tabular}{lc}
\hline \multicolumn{1}{c}{ Tingkat Pendapat } & Skor Jawaban \\
\hline Sangat Setuju & 7 \\
Setuju & 6 \\
Agak Setuju & 5 \\
Netral & 4 \\
Agak tidak Setuju & 3 \\
Tidak Setuju & 2 \\
Sangat Tidak Setuju & 1 \\
\hline
\end{tabular}

Teknik analisis data ini berkenaan dengan perhitungan untuk menjawab rumusan masalah dan pengajuan hipotesis yang diajukan. Analisis faktor digunakan untuk mereduksi menjadi lebih sedikit dan menjadi lebih fokus dalam menentukan faktor-faktor dimensi manakah yang mempunyai kontribusi signifikan dari variabel loyalitas pelanggan. Analisis jalur adalah suatu teknik untuk menganalisis hubungan sebab akibat yang terjadi pada regresi berganda jika variabel bebasnya mempengaruhi variabel tergantung tidak hanya secara langsung (Rutherford dalam Sarwono, 2006).

Untuk menggunakan analisis jalur, harus ditentukan dulu model jalur yang akan diteliti. Model jalur yang dimaksud bisa dilihat dalam Gambar 2. Model jalur adalah suatu diagram yang menghubungkan antara variabel bebas, perantara, dan tergantung. Pola hubungan ditunjukkan dengan menggunakan anak panah. Anak panah tunggal menunjukkan sebab akibat antara variabel-variabel exogenous atau perantara dengan satu variabel tergantung atau lebih. Anak panah juga menghubungkan kesalahan (variabel residu) dengan semua variabel endogenous masing-masing. Anak panah ganda menunjukkan korelasi antara pasangan variabel-variabel exogenous.

Berikut tahap-tahap yang harus dilakukan pada saat analisis jalur, yaitu (1) Menentukan model diagram jalurnya berdasarkan paradigma hubungan antar variable; (2) Membuat diagram jalur persamaan strukturalnya; (3) Untuk menganalisis menggunakan SPSS, maka harus dilakukan dengan menggunakan dua langkah analisis substruktur, yaitu analisis substruktur 1 kemudian dilanjutkan dengan analisis substruktur 2; dan (4) Analisis substruktur 1 dilakukan dengan cara membuat persamaan struktural dari diagram jalur sebagai berikut.

$$
\mathrm{Y} 1=\mathrm{PY} 1 \mathrm{X} 1+\mathrm{PY} 1 \mathrm{X} 2+\mathrm{C} 1
$$

Di mana:

Y1 $=$ Perceived Switching Cost

$\mathrm{X} 1=$ Kepuasan pelanggan

$\mathrm{X} 2$ = Trust

$\epsilon 1=$ Error

Error merupakan nilai pengaruh yang diakibatkan oleh variabel yang tidak diteliti dalam penelitian. 
Analisis substruktur 2 dilakukan dengan cara membuat persamaan struktural dari diagram jalurnya, yaitu:

$$
\mathrm{Y} 2=\mathrm{PY} 2 \mathrm{X} 1+\mathrm{PY} 2 \mathrm{Y} 1+\mathrm{PY} 2 \mathrm{X} 2+\mathrm{E} 2
$$

Di mana :

$\mathrm{Y} 1=$ Perceived Switching Cost

$\mathrm{Y} 2=$ Loyalitas Pelanggan

$\mathrm{X} 1=$ Kepuasan pelanggan

$\mathrm{X} 2=$ Trust

$\epsilon 2=$ Error

Menghitung persamaan regresi dari masing-masing persamaan di atas; menghitung korelasi antara variabel kepuasan pelanggan, Trust, dan perceived switching cost dengan teknik correllation pearson moment; terakhir adalah menganalisis data yang sudah dihasilkan menggunakan teknik analisis regresi, analisis korelasi dan penghitungan pengaruh langsung dan tidak langsung dari masingmasing variabel untuk kemudian diterjemahkan kedalam data-data statistik.

\section{PEMBAHASAN}

\section{Berdasarkan Analisis Faktor}

Oleh karena variabel bebas dalam penelitian ini adalah loyalitas pelanggan dan biaya beralih yang terdiri dari beberapa faktor yang merupakan dimensi dari variabel loyalitas pelanggan dan biaya beralih, maka perlu dilakukan analisis faktor dengan tujuan mengelompokkan dan mereduksi faktorfaktor dimensi loyalitas pelanggan dan biaya beralih. Analisis faktor dilakukan dengan memasukkan faktor-faktor dimensi loyalitas pelanggan, yaitu kepuasan pelanggan (X1), Trust (X2), dan biaya beralih. Setelah dilakukan analisis factor, maka hasil dari analisis faktor dengan program SPSS 14 adalah sebagai berikut (Tabel 3).

Tabel 3 KMO and Bartlett's Test

\begin{tabular}{ll|l}
\hline $\begin{array}{l}\text { Kaiser-Meyer-Olkin } \\
\text { Adequacy }\end{array}$ & Measure of Sampling & \\
& & .753 \\
Bartlett's Test $\quad$ of & Approx. Chi-Square & 458.530 \\
Sphericity & df & 153 \\
& Sig. & .000 \\
\hline
\end{tabular}

Dari Tabel 3 hasil uji KMO, terlihat bahwa hasil KMO (Kaiser-Meyer-Olkin) $=0.753$ telah memenuhi syarat untuk analisis faktor 0.50. Begitu juga dengan Bartlett's test of sphericity juga signifikan dengan nilai signifikansi 0.000 . Jadi, dapat disimpulkan bahwa analisis faktor dapat diteruskan. Dengan analisis korelasi Anti Image telah diolah oleh SPSS, diperoleh bahwa ada 1 subvariabel yang nilainya di bawah 0.3 , yaitu subvariabel switching-4. Oleh karena itu, data ini harus dibuang dan tidak dimasukkan dalam perhitungan selanjutnya. 


\section{Berdasarkan Analisis Jalur}

Dari model diagram jalur, dapat ditulis 2 persamaan struktural, di mana X1 dan X2 adalah variabel eksogen dan Y1 serta Y2 sebagai variabel endogen. Persamaan strukturalnya sebagai berikut:

$$
\mathrm{Y} 1=\mathrm{PY} 1 \mathrm{X} 1+\mathrm{PY} 1 \mathrm{X} 2+\mathrm{C} 1 \quad \text { (Persamaan Substruktur 1) }
$$

Di mana $\quad \mathrm{Y} 1=$ Biaya beralih $($ Perceived Switching Cost $)$

$$
\begin{aligned}
& \mathrm{X} 1=\text { Kepuasan Pelanggan } \\
& \mathrm{X} 2=\text { Kepercayaan (Trust) } \\
& € 1=\text { Error }
\end{aligned}
$$

Dengan menggunakan analisis regresis linear, maka diperoleh data dari SPSS 14.0 (Tabel 4).

Tabel 4 Model Summary

\begin{tabular}{lrlll}
\hline Model & R & R Square & $\begin{array}{c}\text { Adjusted R } \\
\text { Square }\end{array}$ & $\begin{array}{c}\text { Std. Error of } \\
\text { the Estimate }\end{array}$ \\
\hline 1 & $.604(\mathrm{a})$ & .365 & .333 & 3.438 \\
\hline
\end{tabular}

Predictors: (Constant), Satisfaction, Trust

Besarnya angka R square adalah 0.365 . Angka ini digunakan untuk melihat besarnya pengaruh kepuasan pelanggan dan kepercayaan terhadap biaya beralih, dengan cara menghitung koefisien (KD) dengan menggunakan rumus sebagai berikut.

$$
\begin{aligned}
& \mathrm{KD}=\mathrm{r} 2 \times 100 \% \\
& \mathrm{KD}=0.365 \times 100 \% \quad \mathrm{KD}=36,5 \%
\end{aligned}
$$

Nilai KD di atas menunjukkan bahwa pengaruh Satisfaction dan Trust terhadap Perceived Switching Cost secara gabungan adalah sebesar 36,5\%. Sedangkan sisanya sebesar 63,5 \% (100\%36,5\%) dipengaruhi oleh faktor lain di luar variabel Satisfaction dan Trust. Untuk menguji hipotesis, digunakan tabel ANOVA (Tabel 5).

Tabel 5 Anova

ANOVA

\begin{tabular}{|ll|r|r|r|r|r|}
\hline Model & & $\begin{array}{c}\text { Sum of } \\
\text { Squares }\end{array}$ & df & Mean Square & F & Sig. \\
\hline 1 & Regression & 265.292 & 2 & 132.646 & 11.222 & $.000^{\mathrm{a}}$ \\
& Residual & 460.994 & 39 & 11.820 & & \\
& Total & 726.286 & 41 & & & \\
\hline
\end{tabular}

a. Predictors: (Constant), satisfaction, Trust

b. Dependent Variable: switch

Hipotesisnya berbunyi sebagai berikut.

H0 = Tidak ada hubungan linier antara Trust dan Satisfaction terhadap Perceived Switching Cost H1 = Ada hubungan linier antara Trust dan Satisfaction terhadap Perceived Switching Cost

Pengujian dilakukan dengan 2 cara, yaitu (1) Membandingkan besarnya angka F penelitian dengan F table; dan (2) Membandingkan angka taraf signifikansi (sig) hasil penghitungan dengan taraf signifikansi 0,05 (5\%). 
Dari hasil perhitungan didapatkan angka $\mathrm{F}$ penelitian sebesar 11,222 > F tabel sebesar 3.25 sehingga $\mathrm{H} 0$ ditolak dan $\mathrm{H} 1$ diterima. Artinya bahwa ada hubungan linier antara Satisfaction dan Trust dengan Perceived Switching Cost. Dengan demikian, model regresi di atas sudah layak dan benar. Kesimpulannya adalah Satisfaction dan Trust secara gabungan mempengaruhi Perceived Switching Cost dengan besar $36,5 \%$. Sedangkan besarnya pengaruh variabel lain yang sebesar $63,5 \%$.

Cara kedua dilakukan dengan membandingkan besarnya angka taraf signifikansi (sig) penelitian dengan taraf signifikansi sebesar 0,05 . Kriterianya adalah sebagai berikut. Berdasarkan perhitungan SPSS angka signifikansi sebesar 0,000, maka H0 ditolak dan H1 diterima; yang artinya bahwa ada hubungan linier antara Satisfaction dan Trust terhadap Perceived Switching Cost.

Pengaruh Parsial Satisfaction dan Trust terhadap Perceived Switching Cost adalah sebagai berikut. Untuk melihat besarnya pengaruh variabel Satisfaction dan Trust terhadap Perceived Switching Cost secara sendiri-sendiri/parsial, digunakan uji T. Sementara itu, untuk melihat besarnya pengaruh, digunakan angka beta atau Standardized Coeffecient (Tabel 6).

Tabel 6 Standardized Coeffecient

Coefficients

\begin{tabular}{|ll|r|r|r|r|r|}
\hline \multirow{2}{*}{ Model } & \multicolumn{2}{|c|}{$\begin{array}{c}\text { Unstandardized } \\
\text { Coefficients }\end{array}$} & \multicolumn{2}{c|}{$\begin{array}{c}\text { Standardized } \\
\text { Coefficients }\end{array}$} & & \\
\cline { 3 - 5 } & & \multicolumn{1}{|c|}{$\mathrm{B}$} & Std. Error & Beta & $\mathrm{t}$ & Sig. \\
\hline & (Constant) & 16.618 & 3.109 & & 5.345 & .000 \\
& Trust & -.051 & .154 & -.058 & -.333 & .741 \\
& satisfaction & .971 & .262 & .642 & 3.709 & .001 \\
\hline
\end{tabular}

a. Dependent Variable: switch

Hubungan antara Trust dan Perceived Switching Cost adalah sebagai berikut. Berdasarkan hasil penghitungan, diperoleh angka t penelitian sebesar $-0,333<\mathrm{t}$ tabel sebesar 2,021 sehingga $\mathrm{H} 0$ diterima dan $\mathrm{H} 1$ ditolak. Artinya, tidak ada hubungan linier antara Trust dengan Perceived Switching Cost. Kemudian, besarnya pengaruh Trust terhadap Perceived Switching Cost adalah sebesar $-0,058$ atau $5,8 \%$ dan dianggap tidak signifikan.

Hubungan antara Satisfaction dan Perceived Switching Cost adalah sebagai berikut. Berdasarkan hasil penghitungan, diperoleh angka t penelitian sebesar 3.709 $>\mathrm{t}$ tabel sebesar 2,021 sehingga H1 diterima dan H0 ditolak. Artinya, ada hubungan linier antara Satisfaction dengan Perceived Switching Cost. Kemudian, besarnya pengaruh Satisfaction terhadap Perceived Switching Cost adalah sebesar 0.642 atau $64.2 \%$.

\section{Analisis Korelasi}

Analisis korelasi digunakan untuk mencari hubungan keeratan antar variabel. Dalam penelitian ini, untuk menghitung korelasi antara Trust dan Satisfaction dengan hasil perhitungan SPSS (Tabel 7). 
Tabel 7 Korelasi antara Trust dan Satisfaction

\begin{tabular}{|ll|r|r|}
\hline \multicolumn{1}{|c|}{ Correlations } \\
\hline Trust & \multicolumn{1}{|c|}{ Trust } & satisfaction \\
\hline & Pearson Correlation & 1 & $.676^{\star \star}$ \\
& Sig. (2-tailed) & & .000 \\
& $\mathrm{~N}$ & 42 & 42 \\
\hline satisfaction & Pearson Correlation & $.676^{\star \star}$ & 1 \\
& Sig. (2-tailed) & .000 & \\
& $\mathrm{~N}$ & 42 & 42 \\
\hline
\end{tabular}

${ }^{* \star}$. Correlation is significant at the 0.01 level (2-tailed).

Korelasi sebesar 0,676 mempunyai maksud hubungan antara variabel Trust dan Satisfaction sangat kuat dan searah. Korelasi 2 variabel bersifat signifikan karena angka signifikansi $0,000<0,01$. Angka 0,01 digunakan karena hasil penghitungan SPSS memberikan angka signifikansi yang ditandai dengan 2 bintang $(* *)$. Standar SPSS antara 0,01 sampai dengan 0,05 .

$\mathrm{Y} 2=\mathrm{PY} 1 \mathrm{X} 1+\mathrm{PY} 2 \mathrm{Y} 1+\mathrm{C} 2 \quad$ (Persamaan Substruktur 2)

Persamaan strukturnya ialah:

$$
\mathrm{Y} 2=\mathrm{PY} 2 \mathrm{X} 1+\mathrm{PY} 2 \mathrm{Y} 1+\mathrm{PY} 2 \mathrm{X} 2+\mathrm{E} 2
$$

Di mana $\quad \mathrm{Y} 1=$ Biaya beralih $($ Perceived Switching Cost)

$\mathrm{X} 1=$ Kepuasan Pelanggan

$\mathrm{X} 2=$ Kepercayaan (Trust)

Y2 = Loyalitas Pelanggan

$\epsilon 1=$ Error

Dengan menggunakan analisis regresis linear, diperoleh data dari SPSS 14.0 (Tabel 8)

Tabel 8 Model Summary

Model Summary

\begin{tabular}{|l|r|r|r|r|}
\hline Model & R & R Square & $\begin{array}{c}\text { Adjusted } \\
\text { R Square }\end{array}$ & $\begin{array}{c}\text { Std. Error of } \\
\text { the Estimate }\end{array}$ \\
\hline 1 & $.789^{\mathrm{a}}$ & .622 & .592 & 3.433 \\
\hline
\end{tabular}

a. Predictors: (Constant), Trust, switch, satisfaction

Besarnya angka $\mathrm{R}$ square adalah 0.789. Angka ini digunakan untuk melihat besarnya pengaruh kepuasan pelanggan dan kepercayaan terhadap biaya beralih dengan cara menghitung koefisien (KD), dengan menggunakan rumus sebagai berikut.

$$
\begin{aligned}
& \mathrm{KD}=\mathrm{r} 2 \times 100 \% \\
& \mathrm{KD}=0.789 \times 100 \% \\
& \mathrm{KD}=78.9 \%
\end{aligned}
$$

Nilai KD di atas menunjukkan bahwa pengaruh Satisfaction, Trust, dan Perceived Switching Cost terhadap loyalitas pelanggan secara gabungan adalah sebesar 78,9\%. Sedangkan sisanya sebesar $21,1 \%(100 \%-78,9 \%)$ dipengaruhi oleh faktor lain di luar variabel Satisfaction, Trust, dan Perceived Switching Cost. Dengan kata lain, variabilitas loyalitas yang dapat diterangkan dengan menggunakan variabel kepuasan, Trust, Perceived Switching Cost sebesar 78,9\%. Sedangkan pengaruh sebesar $21,1 \%$ disebabkan oleh variabel-variabel lain di luar model ini. 
Untuk mengetahui apakah model regresi di atas sudah benar atau salah, maka diperlukan uji hipotesis. Uji hipotesis menggunakan angka sebagai berikut (Tabel 9).

Tabel 9 Uji Hipotesis

ANOVA

\begin{tabular}{|ll|r|r|r|r|r|}
\hline \multicolumn{2}{|l|}{} & \multicolumn{1}{|c|}{ Sum of } & & & & \\
\hline 1 & Squares & df & Mean Square & F & Sig. \\
\hline & Regression & 737.984 & 3 & 245.995 & 20.869 & $.000^{\mathrm{a}}$ \\
& Residual & 447.920 & 38 & 11.787 & & \\
& Total & 1185.905 & 41 & & & \\
\hline
\end{tabular}

a. Predictors: (Constant), Trust, switch, satisfaction

b. Dependent Variable: loyalty

Pengujian dilakukan dengan 2 cara, yaitu (1) Membandingkan besarnya angka $\mathrm{F}$ penelitian dengan $\mathrm{F}$ tabel. Dari hasil perhitungan, didapatkan angka $\mathrm{F}$ penelitian sebesar 20,869 $>\mathrm{F}$ tabel sebesar 2.85 sehingga H0 ditolak dan H1 diterima. Artinya, bahwa ada hubungan linier antara Satisfaction, Trust, dan Perceived Switching Cost. Dengan demikian, model regresi di atas sudah layak dan benar. Kesimpulannya adalah Satisfaction, Trust, dan Perceived Switching Cost secara gabungan mempengaruhi loyalitas pelanggan, dengan besar 78,9\%. Sedangkan besarnya pengaruh variabel lain sebesar $21,1 \%$.

Cara kedua dilakukan dengan membandingkan besarnya angka taraf signifikansi (sig) penelitian dengan taraf signifikansi sebesar 0,05. Kriterianya adalah sebagai berikut. Berdasarkan perhitungan SPSS angka signifikansi sebesar 0.000, maka H0 ditolak dan H1 diterima. Artinya, bahwa ada hubungan linier antara Satisfaction, Trust, dan Perceived Switching Cost terhadap loyalitas pelanggan.

Mencari pengaruh parsial dari Satisfaction, Trust, dan Perceived Switching Cost terhadap loyalitas pelanggan adalah sebagai berikut. Untuk melihat besarnya pengaruh variabel Satisfaction, Trust, dan Perceived Switching Cost terhadap loyalitas pelanggan secara sendiri-sendiri/parsial, digunakan uji T. Sementara itu, untuk melihat besarnya pengaruh, digunakan angka beta atau Standardized Coeffecient (Tabel 10).

Tabel 10 Angka Beta atau Standardized Coeffecient

Coefficients $^{\mathrm{a}}$

\begin{tabular}{|ll|r|r|r|r|r|}
\hline \multirow{2}{*}{ Model } & \multicolumn{2}{|c|}{$\begin{array}{c}\text { Unstandardized } \\
\text { Coefficients }\end{array}$} & \multicolumn{2}{c|}{$\begin{array}{c}\text { Standardized } \\
\text { Coefficients }\end{array}$} & & \\
\cline { 3 - 5 } & & \multicolumn{1}{|c|}{ B } & Std. Error & \multicolumn{1}{c|}{ Beta } & \multicolumn{1}{c|}{ t } & \multicolumn{1}{c|}{ Sig. } \\
\hline & (Constant) & -6.404 & 4.087 & & -1.567 & .125 \\
& satisfaction & .057 & .304 & .029 & .187 & .853 \\
& switch & .472 & .160 & .370 & 2.955 & .005 \\
& Trust & .622 & .154 & .546 & 4.031 & .000 \\
\hline
\end{tabular}

a. Dependent Variable: loyalty

Hubungan antara kepuasan dan loyalitas pelanggan adalah sebagai berikut. Berdasarkan hasil penghitungan, diperoleh angka $\mathrm{t}$ penelitian sebesar $0.187<\mathrm{t}$ tabel sebesar 2,021 sehingga H0 diterima dan H1 ditolak. Artinya, tidak ada hubungan linier antara kepuasan dan loyalitas. Kemudian, besarnya pengaruh kepuasan terhadap loyalitas pelanggan adalah sebesar 0.029 atau $2.9 \%$ dan dianggap tidak signifikan. 
Hubungan antara Trust dan loyalitas pelanggan adalah sebagai berikut. Berdasarkan hasil penghitungan, diperoleh angka $\mathrm{t}$ penelitian sebesar $4.031>\mathrm{t}$ tabel sebesar 2,021 sehingga H1 diterima dan H0 ditolak. Artinya, ada hubungan linier antara Trust dan loyalitas pelanggan. Kemudian, besarnya pengaruh Trust dan loyalitas pelanggan adalah sebesar 0,546 atau 54,6\%.

Hubungan antara Perceived Switching Cost dan loyalitas pelanggan adalah sebagai berikut. Berdasarkan hasil penghitungan, diperoleh angka t penelitian sebesar 2.955 $>\mathrm{t}$ tabel sebesar 2,021 sehingga H1 diterima dan HO ditolak. Artinya, ada hubungan linier antara Perceived Switching Cost dan loyalitas pelanggan. Kemudian, besarnya pengaruh Trust dan loyalitas pelanggan adalah sebesar 0,370 atau $37,6 \%$.

\section{Analisis Korelasi}

Analisis korelasi digunakan untuk mencari hubungan keeratan antar variabel. Dalam penelitian ini, untuk menghitung korelasi antara Trust dan Satisfaction dengan hasil perhitungan SPSS (Tabel 11). Korelasi antara Trust dan Satisfaction; korelasi sebesar 0,676 mempunyai maksud hubungan antara variabel Trust dan Satisfaction sangat kuat dan searah. Korelasi 2 variabel bersifat signifikan karena angka signifikansi $0,000<0,01$. Angka 0,01 digunakan karena hasil penghitungan SPSS memberikan angka signifikansi yang ditandai dengan 2 bintang (**). Standar SPSS antara 0,01 sampai dengan 0,05 .

Korelasi antara Trust dan Perceived Switching Cost; berdasarkan perhitungan diperoleh angka korelasi antara variabel Trust dan Perceived Switching Cost sebesar 0,376. Korelasi sebesar 0,376 memiliki arti bahwa hubungan antara Trust dan Perceived Switching Cost cukup kuat dan searah (karena hasilnya positif) searah. Artinya, jika Trust tinggi, maka Perceived Switching Cost juga tinggi. Korelasi 2 variabel bersifat signifikan karena angka signifikansi sebesar 0,014. Jika angka signifikansi (sig) $<0,05$, hubungan kedua variabel tersebut signifikan.

Korelasi antara Satisfaction dan Perceived Switching Cost; berdasarkan perhitungan diperoleh angka korelasi antara variabel Satisfaction dan Perceived Switching Cost sebesar 0,603. Korelasi sebesar 0,603 memiliki arti bahwa hubungan antara Satisfaction dan Perceived Switching Cost kuat dan searah (karena hasilnya positif) searah. Artinya, jika Trust tinggi, maka Perceived Switching Cost juga tinggi. Korelasi 2 variabel bersifat signifikan karena angka signifikansi sebesar 0,000. Jika angka signifikansi (sig) $<0,01$, maka hubungan kedua variabel tersebut signifikan.

Tabel 11 Korelasi antara Trust dan Satisfaction

Correlations

\begin{tabular}{|c|c|c|c|c|}
\hline & & Trust & satisfaction & switch \\
\hline \multirow[t]{3}{*}{ Trust } & Pearson Correlation & 1 & $.676^{\star *}$ & $.376^{\star}$ \\
\hline & Sig. (2-tailed) & & .000 & .014 \\
\hline & $\mathrm{N}$ & 42 & 42 & 42 \\
\hline \multirow[t]{3}{*}{ satisfaction } & Pearson Correlation & .676 ** & 1 & $.603^{\star \star}$ \\
\hline & Sig. (2-tailed) & .000 & & .000 \\
\hline & $\mathrm{N}$ & 42 & 42 & 42 \\
\hline \multirow[t]{3}{*}{ switch } & Pearson Correlation & $.376^{\star}$ & $.603 * *$ & 1 \\
\hline & Sig. (2-tailed) & .014 & .000 & \\
\hline & $\mathrm{N}$ & 42 & 42 & 42 \\
\hline
\end{tabular}




\section{Perhitungan Pengaruh}

Pengaruh langsung (Direct Effect atau DE); untuk menghitung pengaruh langsung atau DE, digunakan formula sebagai berikut:

Pengaruh variabel Satisfaction terhadap Perceived Switching Cost

$$
\mathrm{X} 1 \rightarrow \mathrm{Y} 1=0,642
$$

Pengaruh variabel Trust terhadap Perceived Switching Cost

$$
\mathrm{X} 2 \rightarrow \mathrm{Y} 1=-0,058
$$

Pengaruh variabel Satisfaction terhadap loyalitas pelanggan

$$
\mathrm{X} 1 \rightarrow \mathrm{Y} 2=0,029
$$

Pengaruh variabel Satisfaction terhadap loyalitas pelanggan

$$
\mathrm{X} 2 \rightarrow \mathrm{Y} 2=0,546
$$

Pengaruh variabel Perceived Switching Cost terhadap loyalitas pelanggan

$$
\mathrm{Y} 1 \rightarrow \mathrm{Y} 2=0,37
$$

Pengaruh tak langsung (Indirect Effect atau IE); untuk menghitung pengaruh tak langsung atau IE, digunakan formula sebagai berikut:

Pengaruh variabel Satisfaction terhadap loyalitas melalui Perceived Switching Cost.

$$
\mathrm{X} 1 \rightarrow \mathrm{Y} 1 \rightarrow \mathrm{Y} 2=(0,642 \times 0,37)=0,23754
$$

Pengaruh variabel Trust terhadap loyalitas melalui Perceived Switching Cost

$$
\mathrm{X} 2 \rightarrow \mathrm{Y} 1 \rightarrow \mathrm{Y} 2=(-0,058 \times 0,37)=-0,02146
$$

Pengaruh Total (Total Effect)

Pengaruh variabel Satisfaction terhadap loyalitas melalui Perceived Switching Cost

$$
\mathrm{X} 1 \rightarrow \mathrm{Y} 1 \rightarrow \mathrm{Y} 2=(0,642+0,37)=1.012
$$

Pengaruh variabel Trust terhadap loyalitas melalui Perceived Switching Cost

$$
\mathrm{X} 2 \rightarrow \mathrm{Y} 1 \rightarrow \mathrm{Y} 2=(-0,058+0,37)=0.312
$$

Pengaruh variabel Satisfaction terhadap loyalitas pelanggan

$$
\mathrm{X} 1 \rightarrow \mathrm{Y} 2=0,029
$$

Pengaruh variabel Trust terhadap loyalitas pelanggan

$$
\mathrm{X} 2 \rightarrow \mathrm{Y} 2=0,546
$$

Diagram jalur model penelitian; dari hasil perhitungan di atas, maka bisa digambarkan diagram jalur model penelitian seperti pada Gambar 3 . 


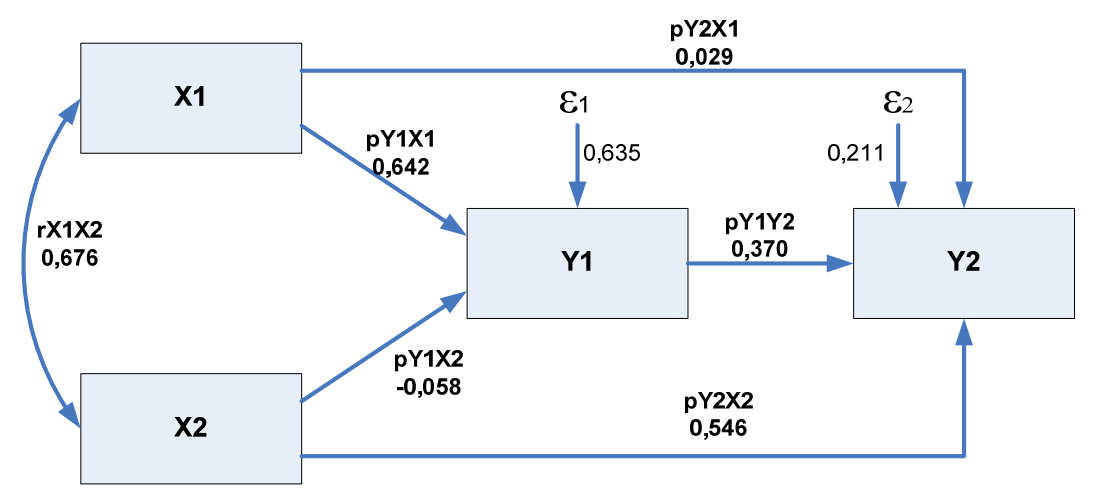

Gambar 3 Diagram Jalur Model Penelitian Loyalitas Pelanggan

Sehingga persamaan struktural untuk model tersebut adalah sebagai berikut:

$\mathrm{Y} 1=0,642 \mathrm{X} 1+-0,058 \mathrm{X} 2+\mathrm{C} 1$

$\mathrm{Y} 2=0,029 \mathrm{X} 1+0,370 \mathrm{Y} 1+0,546 \mathrm{X} 2+\mathrm{\epsilon} 2$

\section{PENUTUP}

Berdasarkan hasil penelitian dan pembahasan yang telah dikemukakan pada bab sebelumnya, maka dalam bab ini akan dikemukakan secara garis besar mengenai simpulan penelitian sebagai berikut. Pertama, pengaruh variabel kepuasan, Trust, dan Perceived Switching Cost terhadap loyalitas secara langsung ini tidak ada hubungan yang signifikan. Sedangkan pengaruh variabel kepuasan, Trust, dan Perceived Switching Cost secara bersama-sama mempengaruhi loyalitas pelanggan. Kedua, pengaruh variabel kepuasan terhadap loyalitas melalui Perceived Switching Cost lebih besar dari pengaruh secara tidak langsung. Dengan demikian, Perceived Switching Cost akan mempengaruhi secara tidak langsung hubungan antara kepuasan dan loyalitas. Ketiga, pengaruh variabel Trust terhadap loyalitas melalui Perceived Switching Cost lebih kecil dari pengaruh secara langsung. Dengan demikian, pengaruh Trust terhadap loyalitas melalui Perceived Switching Cost secara tidak langsung lebih kecil dari pengaruh secara langsung.

Operator GSM harus meningkatkan lagi kepuasan dan loyalitas pelanggan. Hal ini terlihat dengan nilai rata-rata kepuasan $69,7 \%$ dan nilai rata-rata loyalitas pelanggan $78,73 \%$. Dari uji korelasi statistic, terbukti bahwa kepuasan dan Trust, Satisfation, dan Perceived Switching Cost memiliki hubungan yang erat dan positif. Untuk meningkatkan loyalitas pelanggan, perlu dilakukan upaya seperti manajemen harus mulai mengenali multidimensi konstruk dari kepuasan, Trust, Switching Cost, dan loyalitas pelanggan. Mendapatkan pelanggan baru lebih sulit daripada mempertahankan pelanggan baru di iklim kompetisi yang sangat ketat. Untuk meningkatkan loyalitas pelanggan, perlu dibuat agar pelanggan tidak sensitif terhadap harga.

Sensitivitas terhadap harga berarti menurunkan Perceived Switching Cost yang berakibat pindahnya pelanggan ke lain operator sehingga akan menaikkan tingkat customer churn. Karena perubahan teknologi yang begitu cepat di dunia telekomunikasi seluler dan strategi yang berbeda-beda dari masing-masing operator, service menjadi lebih kompleks. Learning period menjadi lebih lama dan proses evaluasi terhadap service menjadi lebih sulit dibandingkan bagi pelanggan. Oleh karena itu, perlu dirumuskan strategi bagi terciptanya switching cost yang tinggi sehingga loyalitas tetap terjaga. 


\section{DAFTAR PUSTAKA}

Aydin, S., and Gokhan, O. (2005). Customer loyalty and the effect of switching cost as variable moderator. Journal of Marketing intelligent and Planning, Emerald.

Aydin, S., and Gokhan, O. (2005). The analysis of antecedent of customer loyalty in turkish mobile telecommunication marketer. European Journal of Marketing, Emerald.

Berry, P. (1998). Service marketing, Mc Millan Inc.

Caruana, A. (2000). Service loyalty the effects of service quality and the mediating role of customer satisfaction. European Journal of Marketing, Emerald.

Kotler, P. (2001). Principle of marketing, Prentice Hall.

Lim, H. (2006). M-Loyalty=winning strategies for mobile carrier. Journal of Consumer Marketing, Emerald.

Sarwono, J. (2007). Analisis jalur untuk riset bisnis dengan SPSS, Yogyakarta: ANDI.

Tjiptono, F. (1997). Prinsip-prinsip total quality services, Yogyakarta: ANDI.

Tjipton, F. (2006). Pemasaran jasa, Yogyakarta: ANDI.

Zeithaml, V.A. (1988). Customer's perception of price, quality, and value. Journal of Marketing. 